Syntax Fusion : Jurnal Nasional Indonesia

P-ISSN: $x x x x-x x x x$

E-ISSN : $x x x x-x x x x$

Vol. 1, No. 2, Februari 2021

\title{
HAK KEBEBASAN BERPENDAPAT YANG SEMAKIN MENYEMPIT DAN MEMBURUK
}

\author{
Chica Septia Ningsih, Crise Amelia, Putri Aisyah, Rifka Zahera, Widya Ika \\ Prasetya \\ Universitas Islam Negri Syarif Kasim Riau \\ E-mail: 12010224754@students.uin-suska.ac.id,12010222529@students.uin- \\ suska.ac.id, 12010221033@ students.uin-suska.ac.id, \\ 12010224917@students.uin-suska.ac.id,12010224810@ students.uin- \\ suska.ac.id
}

\begin{abstract}
Abstrak
Bidang pokok keadilan adalah susunan dasar masyarakat semua institusi sosial, politik, hukum dan ekonomi; karena susunan institusi sosial itu mempunyai pengaruh yang mendasar terhadap prospek kehidupan individu. Memang terdapat berbagai masalah pokok di mana kategori adil dan tidak adil dapat diterapkan. John Rawls memusatkan diri pada bidang utama keadilan yang menurut dia adalah susunan dasar masyarakat. Susunan dasar masyarakat meliputi konstitusi, pemilikan pribadi atas sarana-sarana produksi, pasar kompotitif dan susunan keluarga monogami. Kebebasan berpendapat menjadi hak setiap individu sejak ia lahir, dan tidak dapat diambil ataupun diatur oleh orang lain dalam menyampaika pendapat.
\end{abstract}

Kata Kunci: Pancasila ,Pendapat

\section{Pendahuluan}

Demokrasi merupakan pandangan hidup yang mengutamakan persamaan hak dan kewajiban serta perlakuan yang sama bagi semua warga negara. Awal istilah "demokrasi" dapat dilihat melalui peradaban Yunani kuno yang bercorak polis. Sistem ini didasarkan pada mayoritas dalam pemungutan suara. Demokrasi secara luas mampu diterima dibandingkan dengan sistem lainnya. Sebagian besar negara di dunia telah melaksanakan praktek dari sistem demokrasi. Sistem ini lebih unggul dibanding dengan sistem lainnya disebabkan karena demokrasi memberikan perlindungan terhadap hak asasi manusia (HAM) (Faridah, 2019).

Menurut Aristoteles, suatu negara bisa dikatakan baik jika diarahkan pada kepentingan umum, untuk semua individu rakyatnya, sedangkan jika diarahkan ke penguasa ia dikategorikan buruk. Landasan negara demokratis adalah kebebasan. 
Negara yang diperoleh melalui perjuangan yang cukup lama dan memakan banyak korban, maka kata demokrasi mempunyai arti penting yang telah dicapai. Kemerdekaan yang telah dicapai tersebut harus diisi dengan sistem demokrasi yang berkeadilan. Dengan demikian nantinya demokrasi akan jauh lebih bermakna sebab telah terpenuhinya nilai-nilai hak asasi manusia untuk berekspresi dengan segala kebebasan yang positif dan bukan kebebasan yang anarkis. Maka tahapan demokrasi yang benar dan baik harus dikedepankan sehinggananti akan dijumpai suatu masyarakat yang hidup dalam suasana yang sejahtera dengan koridor hukum yang berlaku.

Kebebasan mengeluarkan pendapat merupakan salah satu hak asasi yang dimiliki oleh setiap manusia dan dijamin dalam UUD 1945. Pancasila sebagai pandangan hidup, dasar negara dan pemersatu bangsa Indonesia yang majemuk sangat menjunjung tinggi kebebasan warga negaranya untuk bebas mengemukakan pendapatnya. Dalam perspektif Pancasila, kebebasan merupakan kebebasan yang terkandung dalam setiap butir-butir Pancasila. Memahami pengertian Pancasila, bahwa menurut tata bahasa Indonesia berarti Lima Dasar: panca berarti lima, sedangkan sila berarti dasar kesusilaan. Kebebasan berpendapat di Indonesia hampir tidak terealisasikan sesuai dengan yang tertera di Pancasila. Semua kebebasan berpendapata tidak berjalan sesuai dengan semestinya. Bagi sebuah negara yang saat ini berkembang kebebasan berpendapat sangat diperlukan agar negara ini terus berkembang menuju negara yang demokrasi.

Kebebasan berpendapat merupakan hak setiap individu sejak dilahirkan yang telah dijamin oleh konstitusi. Maka, Negara Indonesia sebagai negara hukum dan demokratis berwenang untuk mengatur dan melindungi pelaksanaannya. Kemerdekaan berpikir dan mengeluarkan pendapat tersebut diatur dalam perubahan keempat UndangUndang Dasar Republik Indonesia tahun 1945 Pasal 28 E ayat (3) Setiap orang berhak atas kebebasan berserikat, berkumpul, dan mengeluarkan pendapat. Kebebasan berekspresi termasuk kebebasan berpendapat merupakan salah satu hak paling mendasar dalam kehidupan bernegara. Undang-undang No. 9 Tahun 1998 tentang Kemerdekaan Menyampaikan Pendapat di muka umum pasal 1 ayat (1) kemerdekaan menyampaikan pendapat adalah hak setiap warga negara untuk menyampaikan pikiran dengan lisan, tulisan, dan sebagainya secara bebas dan bertanggung jawab sesuai dengan ketentuan peraturan perundang-undangan yangberlaku.

\section{Metode Penelitian}

Dalam menuliskan makala ini, banyak mengandalkan dokumen-dokumen yang digunakan dan dianalisa terlebih dahulu agar mendapat hasil yang bagus dan memuaskan, maka dicarilah informasi yang jelas, agar mendapat bukti yang kuat. Berdasarkan Uraian latar belakang masalah diatas, maka penulis menuliskan rumuskan Permasalahan yang akan diteliti adalah sebagai berikut : 
Apakah menyempitnya kebebasan berpendapat itu sesuai dengan pancasila, teori , dan undang-undang nomor 40 tahun 1999 tentang pers ?. kemudian hal apa saja yang dapat mempersulit kita untuk berpendapat, dan hal apa

saja yg dapat dikemukakan dalam berpendapat.

Semua artikel- artikel ini dapat di akses dengan cara online dan hal ini tertuju pada kebebasan dalam berpendapat. Artikel yang kamindapat juga sesuai denagan kebebasan berpendapat, dan dapat di akses dengan mudah, dan dalam berita yang jelas

\section{Pembahasan}

\section{A. Menyempitnya Kebebasan Berpendapat Menurut Teori, Pancasila, dan Undang-Undang}

\section{Menurut Teori}

Teori kebebasan berarti setiap orang dapat melakukan segala sesuatu dengan bijak dan sesuai dengan keinginannya sendiri. Prinsip umum keadilan, yang menjadi dasar dan interpretasi dari keputusan moral yang perlu diperhatikan dalam keadaan khusus. Kebebasan adalah salah satu hak dasar semua orang. Setiap orang berhak menjadi individu, dengan hak dasar seperti bertindak, berpikir, dan berinter Menurut Paul Sieghart, kebebasan ini adalah tentang memanusiakan keingintahuan kita, memperoleh informasi tentang lingkungan sekitar kita, mengkonstruksi semua pemikiran, keyakinan dan impian, bagaimana memandang dunia, bertukar pikiran, melalui Pikiran menyampaikan gagasan, mempelajari pengalaman, dan berbagai hal. Bidang budaya, sosial, ilmiah atau seni. Inilah perbedaan antara manusia dengan makhluk lain, yaitu hak untuk mengontrol otonomi dan kebebasannya sendiri.

Namun, ada celah yang membatasi kebebasannya, yakni kebebasan orang lain. Pada gilirannya, ini harus memungkinkan umat manusia untuk mentolerir hak orang lain.aksi dengansiapapun.

Kedua prinsip utama ini sangat erat kaitannya dengan prinsip kebebasan. Setiap orang memiliki hak dasar yang menjadi dasar kebebasan, dan ini juga berlaku untuk orang lain. Dalam hal ini kebebasan dasar warga negara adalah kebebasan politik, yaitu hak memilih dan status publik, kebebasan berbicara dan berkumpul, kebebasan hati nurani dan kebebasan berpikir, kebebasan memiliki harta benda, dan kebebasan dari penahanan dan penyitaan semena-mena. . Penegakan keadilan membutuhkan kebebasan ini agar semua orang memiliki hak dan status yang sama.

Namun, terkadang sistem dan struktur sosial masyarakat tidak pernah memperlakukan manusia dengan setara dan bebas sepenuhnya. Penindasan dan penegakan gagasan, ideologi dan kepercayaan masih meluas. Bahkan dalam masyarakat demokratis, sistem sosial dirancang dan dikembangkan untuk memiliki hak-hak dasar ini. Namun institusiseperti negara belum melakukan keadilan terhadap warga negara. Tidak memberikan persamaan dan kebebasan maksimal bagi seluruh warganya. Bahkan di negara demokrasi, pelanggaran hak- hak ini terjadi dimana-mana. 
Sebagai pribadi yang rasional, masyarakat mengharapkan masyarakat melakukan tindakan untuk mencapai kebebasan guna menegakkan prinsip keadilan. Tujuan utamanya adalah untuk mewujudkan kemanfaatan semua. Setiap orang akan lahir sesuai dengan takdirnya sendiri dan akan berada dalam tatanan sosial tertentu. Negara memikul tanggung jawab utama. Sekalipun tampak sulit, negara harus menggunakan institusi dan kekuasaannya untuk melindungi kebebasan semua warga negara. Ini melibatkan salah satu konsep lokasi asli. Negara harus memperlakukan semua warga negara secara setara di depan hukum, tanpa memandang agama atau ras mereka.

\section{B. Kebebasan Berpendapat}

Kebebasan berpendapat umum adalah bagian dari hak asasi manusia (HAM). Kebebasan setiap warga negara untuk menyampaikan pendapat di depan umum merupakan perwujudan demokrasi dalam masyarakat, negara dan tatanan kehidupan di negara tersebut. Hak Asasi Manusia adalah hak dasar atau hak dasar yang lahir dari manusia, dan merupakan pemberian dari Tuhan. Hak asasi manusia pada hakikatnya mencakup dua hak yang paling dasar, yaitu hak atas persamaan dan hak atas kebebasan. Hak asasi manusia lainnya lahir dari dua hak dasar tersebut, atau tanpa kedua hak dasar tersebut maka hak asasi manusia lainnya sulit untuk dipertahankan.

Saat ini kebebasan berpendapat Indonesia didasarkan pada persentase penduduk yang menyatakan pendapat, dan menurut bukti yang nyata saat ini, kebebasan berpendapat Indonesia tergolong tinggi karena Indonesia saat ini merupakan negara yang demokratis di berbagai bidang.

Saat ini, warga negara secara legal dapat menyampaikan kritiknya terhadap setiap kebijakan publik yang dirumuskan oleh pemerintah dan lembaga negara, sehingga apabila kebijakan tersebut tidak memenuhi tujuan kebijakan publik tersebut maka kebijakan tersebut dapat dikendalikan oleh masyarakat sendiri.

Belakangan ini, berbagai organisasi yang didedikasikan untuk kebebasan berekspresi telah bermunculan. Tujuan dari sebagian besar organisasi yang ada adalah menjadi sarana bagi warga negara untuk menyampaikan semua pendapat dan saran mereka, pendapat dan saran ini akan dikomunikasikan oleh organisasi-organisasi ini atau membantu parapengambil keputusan untuk mendengarkan.

Menjadikan kehidupan negara dan negara saling mengikat. Namun, proses kebebasan berbicara di Indonesia tidak terlepas dari penyalahgunaan kebebasan berbicara, karena penyalahgunaan kebebasan berbicara dapat mengakibatkan perpecahan jangka panjang.

Karena kurangnya kontrol, kebebasan berbicara disalahgunakan. Tanpa kontrol yang jelas, warga akan terlalu percaya bahwa semua kebijakan yang merugikan diri sendiri dan organisasinya akan ditentang dengan alasan kebebasan berpendapat dan dianggap sebagai kebijakan yang tidak relevan. Oleh karena itu, kebebasan untuk 
melampaui batasan tersebut akan mengarah pada perpecahan negara ini. Artinya, sebagian kecil dari kebebasan berpendapat Indonesia berada di luar cakupan ekspresi opini.kemerdekaan mengemukakan pendapat di muka umum harus berasaskan keseimbangan antara hak dan kewajiban, musyawarah dan mufakat, kepastian hukum dan keadilan, proporsional yaitu bekerja sesuai latihan, manfaat maksudnya mengeluarkan pendapat tidak untuk diri sendiri tetapi juga untuk orang lain.

\section{Minoritas Menguasai Mayoritas}

Negara Kesatuan Republik Indonesia adalah negara hukum dan demokrasi yang memiliki kekuasaan untuk mengatur dan melindungi penyelenggaraan kebebasan berpendapat. Amandemen Keempat UUD 1945 memberikan kebebasan berpikir dan berekspresi. (2) Setiap orang berhak atas kebebasan berserikat, berkumpul dan berekspresi. Kebebasan berbicara termasuk dalam kebebasan berpendapat yang merupakan salah satu hak paling dasar dalam kehidupan suatu negara. Undang-Undang Nomor 9 September 1998. Mengenai kebebasan berekspresi dalam Pasal 1 ayat (1) Pasal Publik, kebebasan berekspresi adalah setiap warga negara harus bebas mengekspresikan dirinya secara lisan dan tertulis sesuai dengan ketentuan peraturan perundangundanganyangberlaku.

Indonesia adalah negara yang diatur oleh hukum, dan tentunya ada peraturan perundang-undangan yang melindungi hak asasi manusia. Keberadaan hak asasi manusia sebenarnya tidak diberikan oleh negara, tetapi hak asasi manusia hipotetis adalah hak individu yang bersifat supranatural, dan setiap orang memilikinya sejak lahir. Setiap masyarakat di Indonesia memiliki hak untuk berbicara dan menyampaikan pendapat, tanpa memandang ras, ras, atau agamanya. Teknologi informasi saat ini menjadi pedang bermata dua, karena tidak hanya membantu meningkatkan kesejahteraan, kemajuanmanusiadanperadaban, tetapi juga sarana efektif untuk perilaku ilegal.

Pengiriman dan penyebaran informasi melalui media cetak dan elektronik biasanya mengikuti aturan umum masyarakat.

Dalam Pasal 2 ayat (1), Ketetapan Nomor 9 Tahun 1998 disebutkan: "Setiap warga negara, baik individu maupun kelompok bebas, mengungkapkan pandangannya sendiri- sendiri, yang mewujudkan kehidupan demokrasi di negara tersebut sebagai masyarakat dan negara. Hak dan tanggung jawab.tujuan kebebasan berpendapat di depan umum adalah untuk mewujudkan kebebasan yang bertanggung jawab sesuai dengan "Pancasla" dan UUD 1945, sebagai salah satu sarana untuk mewujudkan hak asasi manusia, dan mewujudkan hukum yang konsisten dan berkelanjutan dalam rangka menjamin kebebasan berekspresi.

Untuk melindungi dan menciptakan lingkungan yang kondusif, guna mengembangkan partisipasi dan kreativitas, warga negara sebagai perwujudan hak dan 
kewajiban dalam kehidupan berdemokrasi telah memperoleh tanggung jawab sosial dalam bermasyarakat, bernegara, dan bernegara tanpa mengabaikan kepentingan individu. atau kelompok.Politik Indonesia aktif dalam topik-topik seperti hukum Islam, masyarakat sipil, dan multikulturalisme. Para pemimpin politik sering berpidato. Tentunya apa yang diucapkan dari mulut seorang politikus memiliki makna yang harus didengar. (Wisnu Dewantara, 2016)

\section{Pengaruh Oligarki dalam Demokrasi}

Hal yang menyatakan kebebasan berpendapat tercantum di dalam pancasila yang berbunyi ; "Kerakyatan Yang Dipimpin Oleh Hikmat Kebijaksanaan Dalam Permusyawaratan Perwakilan", yang memiliki arti sebagai berikut :

\section{a. Kekuasaan Rakyat Adalah Segalanya}

Makna dari empat sila pertama Pancasila adalah bahwa sebenarnya rakyat Indonesia memiliki kedaulatan tertinggi di negaranya yang menjadi pedoman dalam melaksanakan setiap keputusan pemerintah. Hal ini karena hak dan kewajiban warga negara lebih berperan dalam partisipasi atau partisipasidalampembangun.

\section{b. Menghargai Keputusan}

Makna dari empat prinsip Pancasila dalam kehidupan berbangsa dan bernegara adalah saling menghormati dan menghargai setiap keputusan yang disepakati bersama. Ini penting karena bisa menghilangkan segala macam konflik di masyarakat.

\section{c. Demokrasi}

Makna sila keempat Pancasila adalah menegakkan demokrasi dari segala aspek kehidupan bermasyarakat. Di bidang politik nasional, hubungan ekonomi dan budaya dan manajemen sosial.

\section{d. Mufakat}

Makna dari keempat sila Pancasila lainnya adalah membuat berbagai bentuk pengambilan keputusan secara kolektif, keputusan bersama tersebut mengutamakan berbagai prinsip sesuai dengan ideologi adat masyarakat, yaitu musyawarah yang mencari mufakat.

\section{e. Berani Bertanggung Jawab}

Arti dari empat prinsip terakhir Pancasila adalah memberikan tanggung jawab untuk melaksanakan keputusan. Mengingat tidak adanya rasa tanggung jawab maka kebijakan tersebut akan melenceng dari seluruh kebutuhan masyarakat, hal ini tentunya merupakan hal yang mutlak dan akan kita bahas secara detail.

Sebagai negara demokrasi, kebebasan berbicara merupakan hak sosial yang penting. Namun, kebebasan semacam ini lebih dari sekedar slogan "Biarkan bebas, biarkan pergi." Sebagai demokrasi konstitusional, segala tindakan yang dilakukan di negara ini harus berdasarkan konstitusi yang ditanamkan oleh Pancasila. Ini juga termasuk masalah kebebasan berbicara. Thomas Pureklolon percaya bahwa kunci untuk 
menciptakan suasana kebebasan berbicara terletak pada mengikuti mekanisme yang ada. Tentunya mekanisme ini bersumber dari peraturan perundang-undangan yang berlaku bagi masyarakat, seperti Pancasila, UUD 1945 dan peraturan perundang-undangan terkait. Ini bertujuan agar Indonesia menjadi negara demokrasi konstitusional.Penegakan hukum secara aktif dalam masyarakat harus didasarkan pada tiga metode sosiologis, yaitu ketika masyarakat mengakui dan menerima keberadaan hukum maka akanPenegakan menurut hukum Jika undang-undang dirumuskan sesuai dengan peraturan yang ditetapkan, maka non penegakan hukum menjadi lebih penting. Norma tingkat tinggi adalah aksioma (Nugraha, 2016)

Tentu saja, penegakan hukum tidak bisa lepas dari kekuasaan. Menerapkan hukum tanpa kekuasaan akan melemahkan hukum, tetapi pelaksanaan kekuasaan juga harus dibatasi oleh hukum. Mochtar Kusumadja menyamakan hubungan antara hukum dan kekuasaan dengan dua aspek yang saling terkait dari sebuah koin. Karena hukum tanpa kekuasaan itu kosong, maka kekuasaan tanpa hukum itu kejam (Nugraha, 2016). Oleh karena itu, dalam kehidupan bernegara demokrasi, negara juga harus memiliki hak untuk memberlakukan pembatasan dalam bentuk asas hukum. Hukum saat ini tidak lepas dari nilai-nilai Pancasila.

Oleh karena itu, dalam kaitannya dengan kebebasan berpendapat, masyarakat harus menggunakan mekanisme kebebasan berpendapat sesuai dengan Undang-Undang Dasar Pancasila. Yakni kebebasan berpendapat berdasarkan ketuhanan, menjaga kemanusiaan, persatuan, demokrasi dan keadilan sosial. Kebebasan berpendapat yang melibatkan ketuhanan bertujuan agar setiap orang menghormati dan menghargai semua kepercayaan setiap orang dan setiap kelompok, karena pada hakikatnya Tuhan adalah konsep universal, dan tidak ada standar atau partikularitas tentang konsep ketuhanan.

Kebebasan berpendapat juga harus memperhatikan nilai-nilai kemanusiaan. Hampir setiap orang memiliki hak untuk mengungkapkan pendapatnya di depan umum dan mengungkapkan suara hati mereka. Jiwa dan ketuhanan Pancasila tidak akan memajukan nama Tuhan untuk kepentingan kelompok, dan tidak akan merendahkan kepercayaan orang lain. Karena pada dasarnya konsep Ketuhanan Yang Maha Esa lebih menekankan pada penghayatan citra Tuhan yang universal, daripada merujuk kepada Tuhan dengan keyakinan dan agama tertentu. Tuhan adalah kepercayaan pada esensi Tuhan, Dia adalah rahmat, penyelamat dan pencipta alam semesta. Kemudian, kebebasan berpendapat yang berdasarkan keadilan dan kemanusiaan yang beradab berarti memperhatikan dan melindungi hak asasi manusia, seperti tidak mengemukakan pendapat yang dapat mengancam hak untuk hidup dan hak dasar lainnya yang diatur dalam Undang-Undang Dasar Negara Republik Indonesia.

\section{Apa Saja Yang Menghambat Kita Untuk Berpendapat}

Hak asasi manusia yang berkenaan dengan penghambatan kita untuk berpendapat yaitu salah satunya adalah adanya pelanggaran yang dilakukan oleh pemerintah ataupun 
kelompok per individu. Dengan pelanggaran tersebut maka terhambatlah keinginan orang lain untuk berpendapat, dikarenakan sudah ada yang melanggar peraturan hak berpendapat. Kita juga tahu bahwa ada undang-undang yang perkenaan berpendapat, namun kita juga harus menjaga sikap kita dalam berpendapat, harus menghormati hak orang lain dan juga sopan santun dalam berpendapat.

Kebebasan berpendapat ini telah jadi bentuk utama dalam berdemokrasi secara modern. Namun, sering kali kebebasan berpendapat ini membuat mereka melanggar peraturan atau norma-norma yang ada. Ataupun pendapat tersebut terkadang tidak sesuai dengan yang kita harapkan, dan hanya sebahagian dari orang tersebut yang mampu menerima perbedaan dari pendapat yang dikemukakan.

Ancaman dalam berpendapat bukan terjadi ada kelompok kecil yang ingin menjadi pembatas kita untuk berpendapat. Namun, ancaman yang sesungguhnya adalah berasal dari sekelompok politik buta yang memberikan izin kepada kita untuk berbicara apa pun yang ingin kita kemukakan dan juga sambil mencoba untuk membungkam pihak yang lain. Berikut ini adalah contoh pelanggaran hak kebebasan dalam berpendapat : Jangan bungkam hak berpendapat masyarakat Papua.Papua kembali melakukan represi anti demokrasi, dengan adanya kekerasan di Papua pemerintah menanggapi dengan cara membungkam kebebasan politik dan menyampaikan pendapat secara damai. Pada tahun 2012 yang lalu Papua melakukan aksi kemanusiaan penggalangan dana untuk tahanan politik yang sakit.Para unjuk rasa ini dibubarkan oleh kepolisian Polsek Abepura dan polres Jayapura dan juga ada sebagian aktivis yang ditangkap.

Kemudian terjadi lagi peristiwa yang sama, di mana pihak kepolisian membubarkan aksi tersebut, aksi yang dilakukan adalah damai dalam memperingati hari masyarakat adat internasional.Marthen juga menegaskan "negara tidak punya hak membungkam kebebasan berpendapat warganya, apalagi mereka ditangkap karena berkumpul dan menuntut pengakuan terhadap hak masyarakat adat, hak atas identitas budaya, dan hak atas pendidikan, ini juga sudah diatur dalamketetapanPBB”.Menurut Martin, kebanyakan kasus pelanggaran HAM yang ada di Papua itu dilakukan oleh aparat keamanan yang diduga merupakan sebuah kejahatan struktural." pelanggaran HAM secara struktural membungkam kebebasan berpendapat masyarakat Papua hal ini tersebut sama dengan membunuh demokrasi di Papua" ujarnya.

Diambildarikutipan“https://www.kompasiana.com/ksatrya.s.p.f/peberpendapat_54 f5e088a33311356e8b4 5d3"Untuk menanggapi tindakan kekerasan yang dilakukan oleh pemerintah, terkhusus dalam kasus kebebasan berkumpul dan berpendapat masyarakat Papua, maka Papua menyampaikan beberapa tuntutan kepada pemerintah.Pertama, menjamin kebebasan bagi masyarakat untuk berpendapat dan berorganisasi tanpa intervensi TNI dan Polri. Kedua, presiden segera mengevaluasi keberadaan militer di Papua. Ketiga, segera melakukan investigasi independen dan transparan dalam mengusut kasus kekerasan yang terjadi di Papua. Keempat, meminta masyarakat internasional agar 
aktif situasi kemanusiaan di Papua yang cukup memprihatinkan. Bentuk HAM seperti itu sangatlah penting untuk diberi perlindungan, pemajuan, penegakan, dan memenuhinya.

Dikarenakan mereka juga perlu hak kebebasan untuk mengungkapkan harapanharapan mereka tanpa adanya pengarangan dan peraturan yang menekan mereka untuk mengungkapkan isi pemikiran mereka.Dan juga agar setiap individu dapat terbebas dari ancaman para petinggi negara yang selalu bertindak semena-mena. Seperti membungkam orang yang ingin mengungkapkanisi pemikiran mereka dengan alasan kepentingan pribadi para petinggi negara tersebut. Bukan hanya untuk kepentingan banyak orang akan tetapi hal tersebut hanya untuk kesenangan individu semata.Solusi untuk menghentikan pelanggaran kebebasan dalam berpendapat tersebut adalah dengan cara menghukum orang yang melanggar hak kebebasan dalam berpendapat dengan hukuman sosial. Dan meninggikan undang-undang tentang hak kebebasan berpendapat tersebut.

Kemudian melakukan sosialisasi kepada pemuda-pemudi bangsa, agar tidak terjadi hal semena-mena dan melanggar hak kebebasan pendapat seseorang. Agar bangsa ini menjadi bangsa yang lebih maju dengan generasi- generasi yang berkualitas.Selain itu juga kita dapat menghukum para petinggi negara, dan menghalangi mereka agar tidak melakukan tindakan yang semena-mena terhadap pemikiran orang lain yang di bawah tingkatan mereka dengan hukuman sosial.Maka dari itu jika kita ingin mengemukakan suatu pendapat secara bersama, kita juga harus mendiskusikannya terlebih dahulu, karena berbeda ada pendapat itu suatu hal yang wajar terjadi pada ada semua orang. Maka dari situlah adanya musyawarah, untuk mendapatkan hasil ataupun kesepakatan bersama. Agar tidak ada konflik dan perpecahan dalam berpendapat.

Dalam kita menyampaikan pendapat kita juga harus beretika

1. Menyampaikan pendapatsecarasopan

Jadi jika kita ingin menyampaikan pendapat harus secara sopan dan juga santun, tidak menggunakan kata yang kasar ataupun dengan cara mencaci maki, bila seperti itu itu akan timbullah rasa sakit hati pada orang lain.

2. Mengetahui kapasitaspengetahuandiri

Jika kita ingin menyampaikan pendapat, kita juga harus tahu kapasitas pengetahuan dalam diri kita, sehingga bila kita menyampaikan suatu pendapat jelasasalusulnya,

Sehingga tidak menimbulkan konflik saat berpendapat.

3. Memiliki argumenyangkuat

Jadi jika kita berpendapat kita harus memiliki argumen yang kuat, agar tidak salah ah dalam berbicara.

4. Tidak memotonglawanbicara 
Pada saat kita berbicara hendaknya kita menyimak dan mendengarkannya dengan baik, dan membiarkan lawan bicara cara menyampaikan pendapatnya hingga selesai, bila sudah selesai maka kemukakanlah apa pendapat anda.

\section{Tidak menyeranglawanbicara}

Saat lawan bicara menyampaikan pendapatnya, janganlah kita menyerang lawan bicara, walaupun kita tidak setuju dengan pendapatnya.

Jadi yang menghambat kita untuk berpendapat ialah tidak diterimanya pendapat, kemudian adanya keputusan langsung dari petinggi negara. Jadi apa pun segala keputusan yang ingin dikemukakan bila telah menjadi ketetapan petinggi negara maka keputusan itu tidak akan bisa diubah.

\section{Ruang Kebebasan Berpendapat dan Berekspresikian Menyempit}

Wakil Ketua Eksternal Komnas HAM RI, Amiruddin Al Rahab menyampaikan belakangan telah terjadi adanya fenomena atau perasaan di masyarakat terkait ruang menyatakan pendapat dan kebebasan berekspresi yang kian menyempit. Perasaan menyempitnya ruang kebebasan pendapat dan berekspresi bahkan bukan dirasakan masyarakat, melainkan juga kalangan jurnalis. Dia bahkan menyebut fenomena itu juga semakin menguat dari hari ke hari. Hal itu disampaikan Amiruddin dalam diskusi daring "Demokrasi dan HAM, Refleksi Setahun Kabinet Jokowi-Amin" yang diselenggarakan Komnas HAM.

"Minggu lalu Komnas HAM menyampaikan pikiran tentang adanya kondisi penyempitan ruang menyampaikan pendapat, berekpresi itu. Oleh karena itu, saya juga ingin sampaikan bahwa Komnas HAM menyatakan itu berdasarkan dari banyaknya aduan yang disampaikan kepada Komnas HAM baik oleh kalangan jurnalis maupun beberapa pihak yang merasa haknya dalam menyatakan pendapat itu tercederai," tutur Amiruddin, Selasa (27/10/2020).

Amiruddin mengatakan kebebasan berpendapat dan berekspresi sebenarnya sudah dijamin oleh konstitusi. Adanya indikasi penyempitan ruang kebebasan tersebut secara langsung berdampak terhadap hak asasi manusia. Karena itu hal tersebut perlu menjadi perhatian serius.menurut Amiruddin, penyempitan ruang kebebasan tidak hanya disebabkan oleh institusi negara, melainkan juga kelompok. Komnas HAM sendiri juga telah menyoroti siapa saja pihak yang kemudian bisa mempersempit ruang menyatakan pendapat dan berekspresi. "Tidak selalu institusi kenegaraan tapi kelompok-kelompok di dalam masyarakat bisa juga mempersempit ruang itu. Artinya apa? Tidak membuka ruang berdiskusi atau berdialog lebih jauh tapi lebih banyak menggunakan tangan aparatur hukum untuk mengatasi perbedaan pendapat dengan kelompok yang lain," kata Amiruddin.

Ia menuturkan penyempitan ruang kebebasan berpendapat dan berekspresi menjadi lebih berbahaya dan berdampak kepada hak asasi manusia lantaran merambah 
kepada jurnalis dan media massa. Di mana, saluran informasi baik dari, oleh dan untuk masyarakat melalui media massa jadi terhambat karena penyempitan ruang kebebasan tersebut. "Tanpa kebebasan pers maka hak asasi manusia juga bisa menjadi berkurang. Kenapa? Karena ada dua hal di dalamnya,"ujarAmiruddin."Pertama hak masyarakat untuk menyatakan pendapat atau aspirasinya bisa melalui media massa atau hak masyarkat untuk mendapat informasi. Karena untuk memperoleh hak asasi manusia itu juga bisa terhalangi ketika media tidak lagi merdeka atau media tidak lagi bebas untuk menyatakan pemberitaan atau meliput atau memberitakan sesuatu," tandasnya.

\section{E. Penyebab Hak Kebasan Yang Kian Menyempit}

Kebebasan berpendapat adalah salah satu hak asasi yang dimiliki oleh setiap warga negara dan ini adalah hak konstitusional yang dijamin oleh negara. Negara Indonesia sebagai negara hukum dan demokrasi berwenang

mengatur dan melindungi pelaksanaan Hak Asasi Manusia. Hal ini diaminkan dalam perubahan keempat Undang- Undang Dasar Negara Republik Indonesia 1945 pada Pasal 28E ayat (3) yang mengemukakan bahwa "setiap orang berhak atas kebebasan berserikat, berkumpul, dan mengeluarkan pendapat." Kemudian penafsiran dari pasal tersebut diakomodir melalui Undang-undang Nomor 9 Tahun 1998 tentang Kemerdekaan Menyampaikan Pendapat di Muka Umum Pasal 1 ayat (1) "kemerdekaan menyampaikan pikiran dengan lisan, tulisan dan sebagainya secara bebas dan bertanggungjawab sesuai dengan ketentuan perundangan yangberlaku."

Beberapa aturan diatas menegasakan bahwa kebebasan berpendapat adalah hak mendasar dalam kehidupan yang dijamin dan dilindungi oleh negara. Implementasi dalam kebebasan berekspresi dapat berupa tulisan, buku, diskusi, atau dalam kegiatan pers. Setiap warga negara secara sah dapat mengemukakan apa yang ada dalam pikirannya, baik berupa kebijakan publik yang dibuat oleh pemerintah dan lembaga negara lainnya. Pendapat atau kritikan atas setiap kebijakan publik merupakan suatu control terhadap jalannya suatu pemerintahan. Hal ini diperlukan agar setiap kebijakan tidak bertentangan dengan HAM dan kebijakan tertuju jelas untuk rakyat. Terdapat empat aspek penting dalam penilaian kondisi demokrasi di Indonesia, 1. Kebebasan Sipil, 2. Partisipasi Sipil, 3. Supermasi Hukum, 4. Perlindungan HAM (Kontran.org).

Lokataru Foundation menilai kebebasan berpendapat di era saat ini mengalami penyempitan ruang ekspresi publik. Hal ini dilihat dari kebijakan pemerintah yang diambil seperti dalam isu Papua, kekerasan dan intimidasi kepada demonstran, Penyempitan kebebasan Akademik, hingga pemberangusan serikat buruh (tirto.id). Baru-baru ini terdapat beberapa kebijakan pemerintah yang menuai kritikan oleh masyarakat. Hal ini dikarenakan kebijakan yang dibuat dinilai menyalahi asas demokrasi dalam bernegara. Seperti yang terjadi pada Agustus lalu di beberapa wilayah provinsi Papua perihal pelambatan akses internet. Hal ini telah menimbulkan kesulitan warga setempat untuk mencari, memperoleh dan menyampaikan informasi melalui media 
telekomunikasi (internet) (Elsam.or.id). Kemudian terror terhadap Ravio setelah ia mengkritik penyajian data kasus Covid-19 oleh BNPB yang dianggap menyesatkan. Tak hanya itu Ravio kerap mengkritik berbagai kebijakan pemerintah (bbc.com). Kemudian terror terhadap penyelenggaraan diskusi dengan tema "Meluruskan Persoalan Pemberhentian Presiden Ditinjau dari Sistem Ketatanegaraan" (tirto.id). Selanjutnya, terror terhadap panitia penyelenggaraan diskusi bertemakan papua (Kompas.com).

Teror terhadap salah satu Stand up comedy bintang emon yang roasting terkait putusan 1 tahun penjara terhadap kasus penyiraman air keras Novel Baswedan (kompas.com). dan Media sebagai ruang publik memberikan dampak positif dalam negara demokrasi. Pasalnya aspirasi publik dapat diserap melalui media sosial. Namun dalam praktiknya terdapat beberapa pelanggaran oleh penggunanya. Kebebasan dalam berekspresi dan berpendapat jelas merupakan bentuk HAM yang tidak boleh dilanggar. Akan tetapi dalam konteks negara demokrasi, keamanan dan kenyamanan bernegara adalah hal yang perlu dijamin oleh pemerintah melalui kewenangannya dalam mengatur suatu negara karena penegakan hukum merupakan variable demokrasi. Dan dalam pasal 19 IICR dan hak berorganisasi/berasosiasi(pasal 21 IICCPR) dapat dijadikan sebagai subjek derogasi (pembatasan atau pengurangan). Subjek dari derogasi sendiri termuat pada pasal 19, pasal 20 dansub-pasal 19 dan 2.Ketentuan pada pasal 20 yang menjadi pagar pembatas kebebasan berekspresi dan menyatakan pendapat. Hal ini untuk mencegah adanya kebebasan berkspresi dalam bentuk tulisan, gambar, maupun audio yang didalamnya berisi seruan atau propaganda untuk perang. Selain itu, pembatasan dalam kebebasan berekspresi juga dibatasi dalam hal menyuarakan akan kebencian atas dasar kebangsaan, ras, agama, yang merupakan suatu tindakan penghasutan untuk melakukan diskriminasi.

\section{Penutup}

Tujuan kebebasan berpendapat di depan umum adalah untuk mewujudkan kebebasan yang bertanggung jawab sesuai dengan "Pancasla" dan UUD 1945, sebagai salah satu sarana untuk mewujudkan hak asasi manusia, dan mewujudkan hukum yang konsisten dan berkelanjutan dalam rangka menjamin kebebasan berekspresi.Untuk melindungi dan menciptakan lingkungan yang kondusif, guna mengembangkan partisipasi dan kreativitas, warga negara sebagai perwujudan hak dan kewajiban dalam kehidupan berdemokrasi telah memperoleh tanggung jawab sosial dalam bermasyarakat, bernegara, dan bernegara tanpa mengabaikan kepentingan individu. Hal yang menyatakan kebebasan berpendapat tercantum di dalam pancasila yang berbunyi Hal ini tentu saja menjadi hal yang mutlak mengingat tanpa adanya rasa tanggung jawab, kebijakan akan menyimpang dari segala kebutuhan masyarakat.dan kami akan merincikan pembahasan tersebut Sebagai negara demokrasi, kebebasan berpendapat merupakan hak yang vital bagi masyarakat.

Oleh karena itu, dalam kehidupan negara yang demokratis, negara tersebut juga harus memiliki hak untuk memberlakukan pembatasan dalam bentuk asas hukum.Oleh 
karena itu, jika dikaitkan dengan kebebasan berpendapat, masyarakat harus menerapkan mekanisme kebebasan berpendapat sesuai dengan konstitusi warga negara Pancasila.Kebebasan berpendapat yang melibatkan ketuhanan bertujuan agar setiap orang menghormati dan menghargai semua kepercayaan setiap orang dan setiap kelompok, karena pada hakikatnya tuhan adalah konsep universal, dan tidak ada ukuran atau kekhususan tentang standar Konsep tuhan.Seorang yang berjiwa Pan- casila dan yang ber-Ketuhanan tidak akan menjual nama Tuhan demi kepentingan golongan dan men- degradasi keyakinan oranglain.

Kemudian, kebebasan berpendapat berdasarkan kemanusiaan yang adil dan beradab berarti memperhatikan dan melindungi hak asasi manusia, seperti tidak mengemukakan pandangan yang dapat mengancam hak atas hidup dan hak dasar lainnya yang diatur dalam Undang- Undang Dasar Negara Republik Indonesia.Kebebasan berpendapat juga harus mengedepankan persatuan, dan selalu diingat bahwa Indonesia adalah negara yang majemuk dan kaya budaya.Hak asasi manusia yang berkenaan dengan penghambatan kita untuk berpendapat yaitu salah satunya adalah adanya pelanggaran yang dilakukan oleh pemerintah ataupun kelompok per individu.

Kita juga tahu bahwa ada undang-undang yang perkenaan berpendapat, namun kita juga harus menjaga sikap kita dalam berpendapat, harus menghormati hak orang lain dan juga sopan santun dalam berpendapat.ataupun pendapat tersebut terkadang tidak sesuai dengan yang kita harapkan, dan hanya sebahagian dari orang tersebut yang mampu menerima perbedaan dari pendapat yang dikemukakan.Namun, ancaman yang sesungguhnya adalah berasal dari sekelompok politik buta yang memberikan izin kepada kita untuk berbicara apa pun yang ingin kita kemukakan dan juga sambil mencoba untuk membungkam pihak yang lain.Marthen juga menegaskan "negara tidak punya hak membungkam kebebasan berpendapat warganya, apalagi mereka ditangkap karena berkumpul dan menuntut pengakuan terhadap hak masyarakat adat, hak atas identitas budaya, dan hak atas pendidikan, ini juga sudah diatur dalam ketetapan PBB'.Menurut Martin, kebanyakan kasus pelanggaran HAM yang ada di Papua itu dilakukan oleh aparat keamanan yang diduga merupakan sebuah kejahatan struktural." pelanggaran HAM secara struktural membungkam kebebasan berpendapat masyarakat Papua hal ini tersebut sama dengan membunuh demokrasi di Papua" ujarnya.

Untuk menanggapi tindakan kekerasan yang dilakukan oleh pemerintah, terkhusus dalam kasus kebebasan berkumpul dan berpendapat masyarakat Papua, maka Papua menyampaikan beberapa tuntutan kepada pemerintah.Dikarenakan mereka juga perlu hak kebebasan untuk mengungkapkan harapan-harapan mereka tanpa adanya pengarangan dan peraturan yang menekan mereka untuk mengungkapkan isi pemikiran mereka.Solusi untuk menghentikan pelanggaran kebebasan dalam berpendapat tersebut adalah dengan cara menghukum orang yang melanggar hak kebebasan dalam berpendapat dengan hukuman sosial.Selain itu juga kita dapat menghukum para petinggi negara, dan menghalangi mereka agar tidak melakukan tindakan yang semena-mena terhadap pemikiran orang lain yang di bawah tingkatan mereka dengan hukuman sosial. 
Menyampaikan pendapat secara sopan Jadi jika kita ingin menyampaikan pendapat harus secara sopan dan juga santun, tidak menggunakan kata yang kasar ataupun dengan cara mencaci maki, bila seperti itu itu akan timbullah rasa sakit hati pada orang lain.Oleh karena itu, saya juga ingin sampaikan bahwa Komnas HAM menyatakan itu berdasarkan dari banyaknya aduan yang disampaikan kepada Komnas HAM baik oleh kalangan jurnalis maupun beberapa pihak yang merasa haknya dalam menyatakan pendapat itu tercederai," tutur Amiruddin, Selasa (27/10/2020).Ia menuturkan penyempitan ruang kebebasan berpendapat dan berekspresi menjadi lebih berbahaya dan berdampak kepada hak asasi manusia lantaran merambah kepada jurnalis dan mediamassa.

Kebebasan berpendapat adalah salah satu hak asasi yang dimiliki oleh setiap warga negara dan ini adalah hak konstitusional yang dijamin oleh negara.Hal ini diaminkan dalam perubahan keempat Undang-Undang Dasar Negara Republik Indonesia 1945 pada Pasal 28E ayat (3) yang mengemukakan bahwa "setiap orang berhak atas

kebebasan berserikat, berkumpul, dan mengeluarkan pendapat." Kemudian penafsiran dari pasal tersebut diakomodir melalui Undang- undang Nomor 9 Tahun 1998 tentang Kemerdekaan Menyampaikan Pendapat di Muka Umum Pasal 1 ayat (1) "kemerdekaan menyampaikan pikiran dengan lisan, tulisan dan sebagainya secara bebas dan bertanggungjawab sesuai dengan ketentuan perundangan yang berlaku." Beberapa aturan diatas menegasakan bahwa kebebasan berpendapat adalah hak mendasar dalam kehidupan yang dijamin dan dilindungi oleh negara.warga negara secara sah dapat mengemukakan apa yang ada dalam pikirannya, baik berupa kebijakan publik yang dibuat oleh pemerintah dan lembaga negara lainnya.Akan tetapi dalam konteks negara demokrasi, keamanan dan kenyamanan bernegara adalah hal yang perlu dijamin oleh pemerintah melalui kewenangannya dalam mengatur suatu negara karena penegakan hukum merupakan variable demokrasi.

\section{Bibliografi}

Dewantara, A. (2019). "The Archaeology of Knowledge" berfokus pada politik dan hubungannya dengan multikultural Indonesia Mahfud MD. , 1999, "Pilar Hukum dan Demokrasi", Gama Media, Yogyakarta. Faridah, S. (2019). Relevansi "Makar" di \# 2019ChangePresident, 4, 238-249.

Wisnu Dewantara, A. (2016). Madrid, 15 April (22 Desember). https://m.liputan6.com/global/read/2947911/7-kasus-yang-mengancamkeberdekaanberpendapat https://www.kompasiana.com/ksatrya.s.p.f/pelanggaran-keberdekaanberpendapat_54f5e $088 \mathrm{a} 33311$

https://journal.unnes.ac.id/sju/index.php/lslr/ https://kontras.org/2019/09/16/siaranpers-hari-demokrasi-internasional-per]-untuk-seluruh-rakyat-demokrasiIndonesia-sedang-di-ujung-tanduk/ 
https://www.google.com/amp/s/amp.tirto.id/lokaratu-sebut-ruang-ekspresipublikselian , D.L. dan Melina, C. (2018). "Kebebasan Berekspresi di Era Demokrasi: Catatan Penegakan hak Ahttps: //elsam.or.id/internet-shutdownpapua-bentuk-repression-digital-dan-menalahi-principled-condition- darurat/ sasi Manusia "," Lex Scientia Legal Review ". November Vol. 2 No.2. Rosana (Ellya). (2016) "The Situation of Democracy and Human Rights", "Tapis Magazine": "Islamic Political Aspirations" No. 12, https://amp.suara.com/news/2020/10/27/161354/komnas-ham-ruangkeberdekaan-berpendapat-and-expression- semakin sempit 